\title{
FISCALITY - A RELEVANT FACTOR INFLUENCING REGIONAL DEVELOPMENT IN ROMANIA AND THE EUROPEAN UNION
}

\author{
Vlad Cristina, Ph.D.Student \\ University of Economic Studies, Bucharest, Romania \\ cristina.vlad8@gmail.com \\ Brezeanu Petre, Ph.D. \\ Faculty of Finance, Insurance, Banking and Stock Exchange, \\ University of Economic Studies, Bucharest, Romania, \\ brezeanupetre@yahoo.com
}

(Received December 2015; Accepted April 2016)

\begin{abstract}
The paper aims to examine taxation in the EU in correlation with regional development measures implemented. We started with the EU vision on regional development. If during the 2007-2013 period, were pursued three major objectives (convergence, regional competitiveness and territorial cooperation), in the current 20142020 funding period, money is allocated differently between countries that are deemed to be more developed, in transition and less developed. These categories are set according to GDP per capita. Next we exposed the fiscal changes made in the EU in 2010-2011 period and then we corelate them with the strategy for regional development for five member states: Romania, Bulgaria, Czech Republic , Hungary and Poland. We used data reported by Eurostat regarding the evolution of unemployment rate and for the foreign direct investments in 2007-2012 period. We also brought up and changes required by the new Romanian Fiscal Code. According to it, measures such as reduction of income tax for new micro enterprises or extending the VAT reverse charge mechanism in many sectors of activity, are meant to encourage foreign capital inflows and also to increase the level of regional development. As a general conclusion, we found that there is a direct link between fiscal policy and regional development; fiscal measures implemented influence the level of unemployment, economic growth, and competitiveness in the private sector.
\end{abstract}

Key words: regional development, fiscal policy, tax

JEL Classification: E62, R11,

Abbreviation used in the paper:

\begin{tabular}{|c|c|c|c|c|c|c|c|}
\hline Belgium & $(\mathrm{BE})$ & Greece & (EL) & Lithuania & (LT) & Portugal & $(\mathrm{PT})$ \\
\hline Bulgaria & (BG) & Spain & $(\mathrm{ES})$ & Luxembourg & (LU) & Romania & (RO) \\
\hline Czech Republic & $(\mathrm{CZ})$ & France & (FR) & Hungary & (HU) & Slovenia & (SI) \\
\hline Denmark & (DK) & Croatia & (HR) & Malta & (MT) & Slovakia & (SK) \\
\hline Germany & (DE) & Italy & (IT) & Netherlands & (NL) & Finland & (FI) \\
\hline Estonia & $(\mathrm{EE})$ & Cyprus & $(\mathrm{CY})$ & Austria & $(\mathrm{AT})$ & Sweden & (SE) \\
\hline Ireland & (IE) & Latvia & $(\mathrm{LV})$ & Poland & (PL) & United Kingdo & (UK) \\
\hline
\end{tabular}


Fiscality - a relevant factor influencing regional development in Romania and the European Union

\section{Introduction}

Regional development policy is an ensemble of measures planned and promoted by the local and central public administration authorities, having as partners different actors in order to ensure a dynamic and lasting economic growth, through the effective use of the local and regional potential, in order to improve living conditions (Popescu M.et al, 2009), the effective and local levels in order to improve living conditions. The main areas where regional policies can be targeted are: enterprise development, labor market, attracting investment, technology transfer, development of Small and Medium Enterprises, infrastructure improvements, environmental quality, rural development, health, education, education, culture (Sabau M., et al ). At the European Union's level, Regional Policy is the main investment policy and is delivered through three main funds: European Regional Development Fund, Cohesion Fund and European Social Fund. All these three institution have the responsability to apply measures and to use appropriate tools in order to accomplish the objectives set. And the real challange comes when authorities must welcome the adoption of this new policy and place it near traditional policies like monetary or fiscal ones. How this can be done? By developing old tools from each economical branch in order to fulfill new goals.

The problem comes when we realize that the effects of the regional development are very difficult to express in value and are not clear. Unlike businesses, in which the effect can be exactly economically quantified, the regional development is created by the public benefits for individuals and groups in the given region. They can be expressed as external and agglomeration economies. External economies arise from the development of the economic base and the interconnectedness of industries in the region as a result of technological innovation or as the effects of urbanization (the concentration of population and built infrastructure). Agglomeration economies flow from complexly built technical and social infrastructure in the area (Durkova K. et al, 2012). More than that, although the effects are not „material ones”, they can become very visible and with strong negative impact on a long term. In the same time, the concept of regional development is not static in nature, but refers to complex space-time dynamics of regions. Changing regional welfare positions are often hard to measure, and in practice we often use Gross Domestic Product (GDP) per capita as a statistical approximation. Sometimes alternative or complementary measures are also used, such as per-capita consumption, poverty rates, unemployment rates, labor force participation rates or access to public services. These indicators are more social in nature and are often used in United Nations welfare comparisons (Nijkamp P. et al, 2009). 
As we mentioned before, the regional development is influenced by the monetary, fiscal and sector policies applied by the government. Through the state budget, there are the interregional redistribution of the taxes and the income on one hand and the costs on the other hand. Economically stronger regions, which include the economic core regions, contribute to the state budget with higher amounts, while the higher amount of resources goes to the peripheral regions through social grants (Durkova K. et al, 2012).

Our research is focused on the relationship between the regional development imposed by the European Union and the fiscal policies chosen by the member states. The main purpose of our paper is to see how member states reacted in the economic crisis time and how they implemented EU recommendations regarding regional development according with the fiscal conditions that had to be changed and to help authorities in collecting more revenues and in deacreasing public expenditure.

We will see in detail that all the member states brought changes in their fiscal system in 2007-2012 period by increasing taxes in one way or another and this strategy can only influence in a negative way indicators such us labour market or the foreign investments volume. Of course, it depends also on how stable every economic and financial system is, because such a change may have different consequences in each country. That way one of the most important objective of this paper is the analysis of the ,side effects" brought by the fiscal changes in four countries from Eastern Europe, that had joined in the same time the EU and they had a similar economic evolution during time. We chose to do such a comparison in order to obtain a fair conlusion about how taxes can influence an entire economic system. Despite the fact that the four countries belong to the same category in the EU division, we will see that in time of crisis the strategies and the evolution turned to be different; and this lead us to the conclusion that a global economic crisis can also change a country vision an on a long term may bring improvements.

We decided to approach this topic because now, in 2016 after we all felt the recession's hard effects, we can look back and see how member states passed the crisis, what they left behind and who managed to make a step forward when everybody else was trying not to fall behind. Regional development always represented an important objective for the Eurpean Union and a challenge for member states. Each period of development had clear and strict rules that had to be respected and step by step this European policy became as important as old policies (e.g: fiscal, monetary) used by every state in this world. Considering that in this period, 2014-2020, the European funds are divided differently, depending on the level of development it means that the creation of a single market is still the most

50 DE GRUYTER OPEN
Studia Universitatis "Vasile Goldis" Arad. Economics Series Vol 26 Issue 2/2016 ISSN: 1584-2339; (online) ISSN: 2285 - 3065.

Web: publicatii.uvvg.ro/index.php/studiaeconomia.Pages $48-62$ 
important objective of the EU. A bigger allocation of funds in countries where is more needed, on a long term, can signifantly contribute to economic growth and regional development.

We believe that this topic treats current issues of not only European Union, but of the world economy and that in the future will be more and more developed if we take into consideration the scale of regional development policy in recent years among the traditional policies applied.

\section{Literature review}

The link between regional development and fiscal policies represented a main topic in many papers and published books over time. Since 1973, the importance of regional policy and its significant role in the immplementation of economic theories was emphasized by Higgins, who was saying that "Measures to reduce regional gaps, far from being a luxury to be afforded when things are otherwise going well in the country, are the essence of a policy to accelerate growth, reduce unemployment and maintain price stability. For developing countries, where efforts to accelerate growth are inhibited by fear of aggravating inflation, reduction of regional disparities may well be the sine qua non of successful development policy" (Higgins, 1977). The statement can be applied also in our days because, as we will see also in our paper further, a region's or country development is strongly related to macroeconomic indicators such as employment rates or foreign investments which can lead fast to economic growth.

A later study made by Reed and Rogers in 2004, examine the effects of 30\% reduction in New Jersey's personal income taxes in 1994-1996 period. They found that counties in New Jersey experienced substantial employment growth subsequent to the tax cut, but so did counties in other states, which did not implement tax cuts. Tax cut is measured by the difference-in-difference estimate that is the increase in employment in New Jersey counties relative to counties in other states in the region - and was small and not significantly different from zero (W. G. Gale et al, 2015). Recently, in 2014 the research was developed by Ljungqvist and Smolyansky, using a longer period of time (1970-2010). They discovered that increases of corporate taxation reduce employment rates, but viceversa is not available, meaning that the reductions in corporate taxation rates doesn't necessarly bring raised employment rates, except during recessions.

Later, in 2003, Mackay R.R. studied the impact of twenty-five years of regional development in UK. He discovered that up to the mid 1970's there was a trend towards greater regional equality in the distribution of income and wealth in the UK. After 1975, regional inequality has increased in UK . Growing inequality has been associated with a more problematic labour market. The growing gap between 
a prosperous Inner Region Core and the rest of the UK is disguised in the unemployment statistics because of a powerful discouraged worker effect in the less prosperous regions. His paper seeks to explore why regional convergence has been replaced by divergence and argues that if spatial imbalances continue, then they are likely to add an inflationary pressure in the UK that may be detrimental to the growth of national output (Mackay R.R., 2003).

In 2014, Daniel Werner used annual average data representing unemployment rates of the ten Western German Federal States (excluding Berlin), in 1968 - 2009 period, to build a model that can reveal whether regional unemployment disparities in Western Germany widen, become narrower or remain constant over time. The findings provide a negative relationship between the initial values of regional unemployment rates and their corresponding growth rates. While a favorable economic climate leads to a rise of regional inequality, regional inequality decreases during economic crisis. This means that during a boom, the unemployment rate decreases slower in regions with higher unemployment rates compared to those with lower unemployment rates. During an economic downturn, however, unemployment increases slower in regions with high unemployment rates compared to those with low unemployment rates. Therefore, a positive economic climate is not sufficient to close the gap between low unemployment regions and high unemployment regions (Daniel Werner, 2014).

A particular research on Romania case was done by Donean A recently, in 2015 when it was analyzed the impact of regional development policy used to reduce economic disparities between the Romanian regions for the period 2007-2013. In this regards, the author analyzed the evolution of different indicators such as the GDP per capita, the foreign investments, the unemployment rate or the number of small and medium enterprises. All these indicators have a strong impact on the regional development policy and some of them are also used in our research. After this research, Donean A. concluded that the authorities in Romania should pay more attention to the solution of the regional disparities and elaborate policies that could attract foreign investors in the less developed regions. The differences among the Romanian regions turned to be very big but dispite this, the author believes that, there is growth potential even if not at the level of the richest EU regions. Firstly, Romania needs to set up priorities for the future development of these regions and secondly, it must set up feasible goals based on the present evidence available in each region, without being influenced by what happens in Europe. It is more than apparent that Romania's regions must follow the example of other EU regions in terms of development rhythm but this does not mean that it should settle goals which are impossible to reach in Romania (Donean A., 2015). Of course that joining EU, has brought many good things for Romania. Eventually, reporting to a 
more developed economy is not a bad thing as long as the targets set are realistic and not unattainable. More than that, Popescu R.G. at all highlighted in one paper published in 2012 that the integration in the European Union and the economic crisis has actually brought a positive evolution on the values of the macroeconomic indicators that determine the location decision in the development regions of Romania (Popescu G.R. et al, 2012).

On the other hand, it is obvious that more developed economies are able to attract more foreign investments and to influence in a positive way the regional development policy. They have the history, the resources and the experience to do this. Things are different when we talk about a country where its regions are very different from the level of development point of view. Wisnewiski A. had shown that the level of development is one of the main determinant of foreign investments location. Experience in the past decades shows a high correlation between GDP and foreign investment per capita, resulting in a multiplied growth effect. Although the foreign investments had played an exceptional role in modernizing some sections of the economy, its overall impact on regional development has been adverse; regional disparities have widened through foreign investments allocation (Wisnewiski A, 2005). And this may happened because once one investor comes in a certain region and offers jobs creation, increases the tax volume collected and starts to invest in infrastructure, the other unchanged regions are falling apart and the differences become bigger; in this time, the economy is developing but without solving the problems regarding disparities between regions.

We believe that the theories regarding regional development and the indicators that may influence it differ from country to country because even if European Union's members follow the same direction, individual goals are set; economies are different and each of it has its own flow. Further, in the next chapters we chose to take a look at the evolution of some key indicators in five similar countries from the development level point of view.

\section{Regional Development strategy in the European Union}

The European Union's regional policy covers all European regions, but they are separated somehow, depending on their economic situation but also on the needs of each state. If during the 2007-2013 period, were pursued three major objectives (convergence, regional competitiveness and territorial cooperation), in the current 2014-2020 funding period, money is allocated differently between countries that are deemed to be: more developed (with GDP per capita of more than $90 \%$ of the EU average), in transition (with GDP per capita between $75 \%$ and $90 \%$ of the EU average) and less developed (with GDP per capita less than $75 \%$ of the EU average). The largest amount of European funds are dedicated to less developed 
Vlad C., Brezeanu P. (2016)

Fiscality - a relevant factor influencing regional development in Romania and the European Union

countries which are mostly East-European countries, including Romania, but also Greece and some parts of Italy, Spain, France and Portugal. The aim of these splitting of money is to allow the regions affected to catch up with the more prosperous regions, thereby reducing economic disparity within the European Union and creating in the end the single market. The strategy for 2020, contains five main targets for European Union and they are illustrated in Table 1. Taking into consideration these official directions, each member state established its own national targets in these areas.

Tabel 1: The five main targets in 2014-2020 Europan Union's strategy

\begin{tabular}{|l|l|}
\hline Employment & $75 \%$ of the 20-64 year-olds to be employed \\
\hline Research and Development & $\begin{array}{l}3 \% \text { of GDP to be invested in research and } \\
\text { development }\end{array}$ \\
\hline $\begin{array}{l}\text { Climate change and energy } \\
\text { sustainability }\end{array}$ & $\begin{array}{l}\text { Greenhouse gas emissions 20\%, 20\% of energy from } \\
\text { renewables, 20 \% increase of energy efficiency }\end{array}$ \\
\hline Education & Reducing the rates of early school leavers below 10\% \\
\hline $\begin{array}{l}\text { Fighting poverty and social } \\
\text { exclusion }\end{array}$ & $\begin{array}{l}\text { At least 20 million fewer people in or at risk of poverty } \\
\text { and social exclusion }\end{array}$ \\
\hline
\end{tabular}

Source: European Comission

We can see that Regional Policy has a strong impact in many fields, it is geared towards making regions more competitive, fostering economic growth and creating new jobs, but also has a role to play in wider challenges for the future, including climate change, energy supply and globalisation.

\section{The interference of fiscal policy and regional development}

Fiscal policy instruments, such as tax incentives, aimed at decreasing regional disparities are essentially means of expanding aggregate demand because tax incentives for investment merely concentrate additional demand in the capital goods sector (Kesselman et al, 1977).

The economic crisis triggered in 2007, led to increased budget deficits and due to these fact 24 countries from European Union received recommendations to decrease the budget deficit below 3\% in 2011-2015 period. To accomplish this goal, most of the member states were focused on increasing the revenues on the one hand and decreasing the expenses on the other hand. And this changes had to be done following in the same time the regional development strategy, meaning that countries had to increase taxes without affecting somehow the labour market or the foreign investments. There were made a lot of changes, but each country adapted its strategy to its national economic and social situations. Most of these changes were made in 2010 and 2011 in order to accelerate fiscal consolidation and 
in Tabel 2 we can see how each member state built its strategy. In general, fiscal policy in the EU was a contractionary one in 2010, although there were also expansionary fiscal measures in some EU member states aimed at mitigating the negative effects of the crisis. Given the need to consolidate public finances, fiscal measures taken in 2011 have focused, in almost all Member States, on increased tax revenue. The trend of increasing taxes in 2011 was accompanied in some Member States also by a reform of the whole tax system. In this way, they tried to move the tax revenue based on distorting taxes (eg. corporate tax and income tax) to less distortionary taxes (consumption taxes and indirect taxes in general). A similar opinion is mentioned also by Radu C.F et al in the paper „Labour taxation a comparative study ,published in april 2015. After studying the evolution of average tax wedge in OECD countries during 2000-2013, the authors that the tax wedge average had a decreasing trend between 2000-2010, when it fell from $36.75 \%$ to $35.11 \%$, and a upward trend starting with 2011 , when the value grew slightly to $35.85 \%$ in 2013 (Radu C.F et al, 2015).

A lot of countries decided to increase the income tax by increasing tax rates, but mostly by broadening the tax base. VAT and excise duties were also increased in most countries, most often in the form of higher rates. Countries with large budget deficits, such as Greece, Portugal, Spain, increased taxation on both income and profit and tax.

Tabel 2: Fiscal changes in 2010-2011 period in European Union

\begin{tabular}{|c|c|c|c|}
\hline Type of tax & Measure & Tax rate & Tax base \\
\hline \multirow[t]{2}{*}{ Income tax } & Increase & $\begin{array}{l}\text { EL, ES, FR, IE, LV, LU, } \\
\text { PT, UK }\end{array}$ & $\begin{array}{l}\text { AT, CY, CZ, DK, EE, ES, } \\
\text { FR, IE, LV, PT, RO, SK, UK }\end{array}$ \\
\hline & Decrease & DE, DK, FI, HU, NL & BG, DE, FI, LT, SE \\
\hline \multirow{2}{*}{$\begin{array}{l}\text { Corporate } \\
\text { (profit) tax }\end{array}$} & Increase & PT & LU, RO \\
\hline & Decrease & CZ, EL, HU, LT, NL, UK & AT, BE, DE, ES, LT, NL \\
\hline \multirow{2}{*}{$\begin{array}{l}\text { Social } \\
\text { contributions }\end{array}$} & Increase & IE, LV & BG, CY, IE, LT, PT, RO, SK \\
\hline & Decrease & BG, HU & \\
\hline \multirow[t]{2}{*}{ VAT } & Increase & $\begin{array}{l}\text { CZ, EL, ES, HU, LV, PL, } \\
\text { PT, RO, SK, UK }\end{array}$ & CZ, EL, ES, FR, PT, LV \\
\hline & Decrease & IE & BE, DE, HU, LT, NL, PL \\
\hline \multirow[t]{2}{*}{ Excise } & Increase & $\begin{array}{l}\text { AT, BG, CZ, DE, DK, EE, } \\
\text { EL, ES, FI, IE, HU, LV, } \\
\text { MT, NL, RO, SL, SK, UK }\end{array}$ & CZ, EL, ES, FR, PT, LV \\
\hline & Decrease & AT, BG, SK & BE, DE, HU, LT, NL, PL \\
\hline \multirow[t]{2}{*}{ Property tax } & Increase & CZ, DE, EL, PT & \\
\hline & Decrease & & \\
\hline
\end{tabular}

Source: European Comission 
A lot of empirical studies and different econometric models confirm that taxes on immovable properties followed by consumption taxes (indirect taxes) seem to be the least detrimental to economic growth. On the other hand, personal income tax, social contributions and, in particular income taxes are found to be most harmful for the economy. This may be one of the reason that supported the decision of most ccountries to increase VAT and excise in such a short term. In fact, direct tax rates were increased in more developed countries, were probably foreign investments or labour market are not so fragile and so easy to destabilize. There were also easteuropean countries that brought changes in direct taxation, but regarding the tax base, not rates.

It is very intersting to notice Bulgaria's strategy. They didn't increased VAT, only excises and in direct taxation they decreased the tax base for income tax and the rate for social contributions. In this way, they had and still have the lowest flat taxes $(10 \%)$ from the European Union for corporate and income tax. The reduction of income tax or of social security contributions have the potential to increase both supply and labor demand leading to a lower unemployment rate and greater use of labor. Reducing corporate tax will reduce the cost of capital and will stimulate the capital accumulation and investment in research and development, which will mean in the end faster economic growth and productivity. Instead, increasing consumption taxes and taxes on real estate affects indirect the accumulation of specific production factors and therefore, will have a more limited impact on economic growth.

In order to compare how these fiscal measures affected the regional development policy which had to be immplemented no matter the crisis effects, we chose to see the evolution of direct foreign investments on the one hand and of unemployment rate on the other hand in five member states: Romania, Bulgaria, Czech Republic and Hungary. We had chosen these countries because they joined the European Union in closed periods of time and because they have a similar economic environment.

In Figure 1, it is plotted the trend of unemployment rate in 2007-2012 period. It can be seen that all the countries saw increased percentages in 2009 when the crisis effects started to be visible on labour market and started to stabilize after 2010, when all five countries changed their fiscal policies by increasing or deacresing tax rates.

Analysing the figure, we can tell that the Romania, Czech Republic and Poland have a quite stable evolution regarding the unemployment rates. All of them decided to change tax system on indirect side, choosing the most simple solution and fast solution in order to increase tax revenues and in the same time not to

56 DE GRUYTER OPEN
Studia Universitatis "Vasile Goldis" Arad. Economics Series Vol 26 Issue 2/2016 ISSN: 1584-2339; (online) ISSN: 2285 - 3065.

Web: publicatii.uvvg.ro/index.php/studiaeconomia.Pages $48-62$ 
Vlad C., Brezeanu P. (2016)

Fiscality - a relevant factor influencing regional development in Romania and the European Union

destabilize labour market, which is so important when we talk about a healtht economic growth. On the other side, Bulgaria and Hungary, they are not so far of their „neighbours”, but they faced with a higher growth of unemplyment rate during and in post crisis time.

Figure 1: The unemploymnet rate in 2007-2012 period

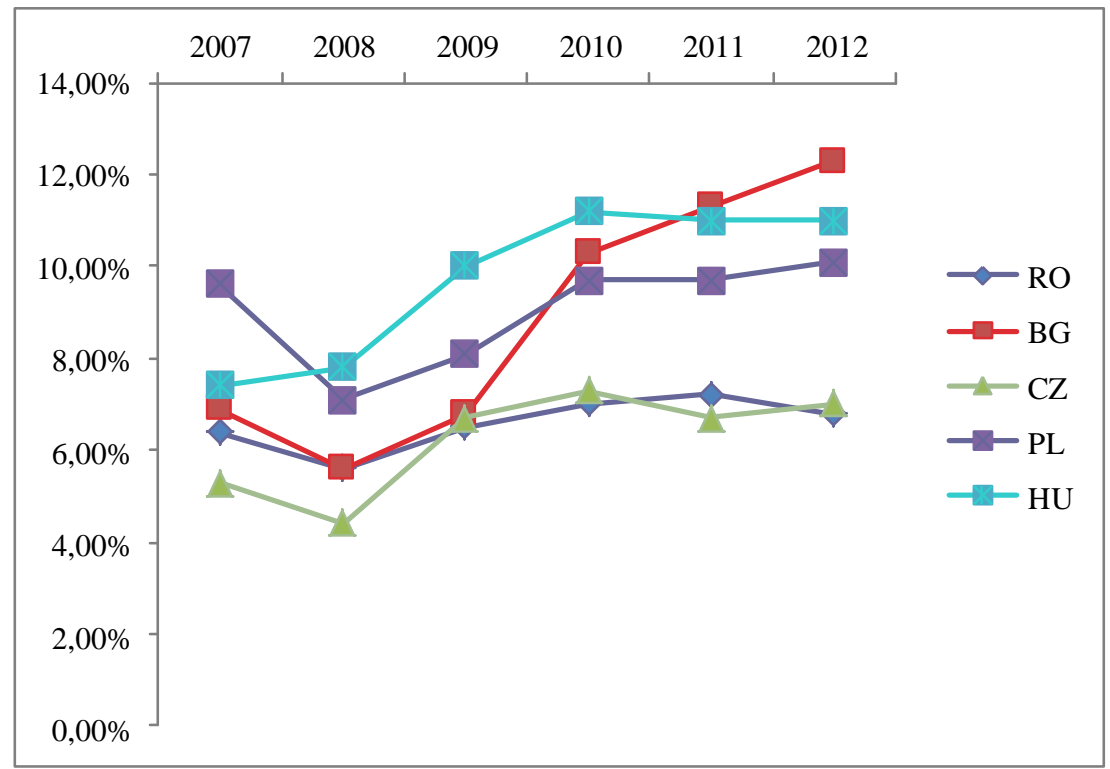

Source: Own representation, using Eurostat dates

Figure no. 2 exposes the evolution of foreign direct investments flows (mil Euro) for the same countries in the same period of time. It can be seen that this time places between them are switched.

Romania is the only country that in 2012 had a negative flow for foreign investments. This means that it is not enough to not change anything on direct taxes side, because the fiscal competition is very tough and investors are choosing stable environments, but also the best fiscal conditions. It can be seen that Bulgaria is not having the biggest flow, but is the most constant one. They offer the lowest flat tax from European Union and with a $10 \%$ tax rate no matter how big your profit or income is, as an investor you will choose to develop your business in Bulgaria. Also, the Czech Republic managed to have a positive value in 2012 and they also practice a lower flat tax comparing with Romania. 
Vlad C., Brezeanu P. (2016)

Fiscality - a relevant factor influencing regional development in Romania and the European Union

\section{Figure 2: Foreign investment flows (mil. Euro) in 2007-2012 period}

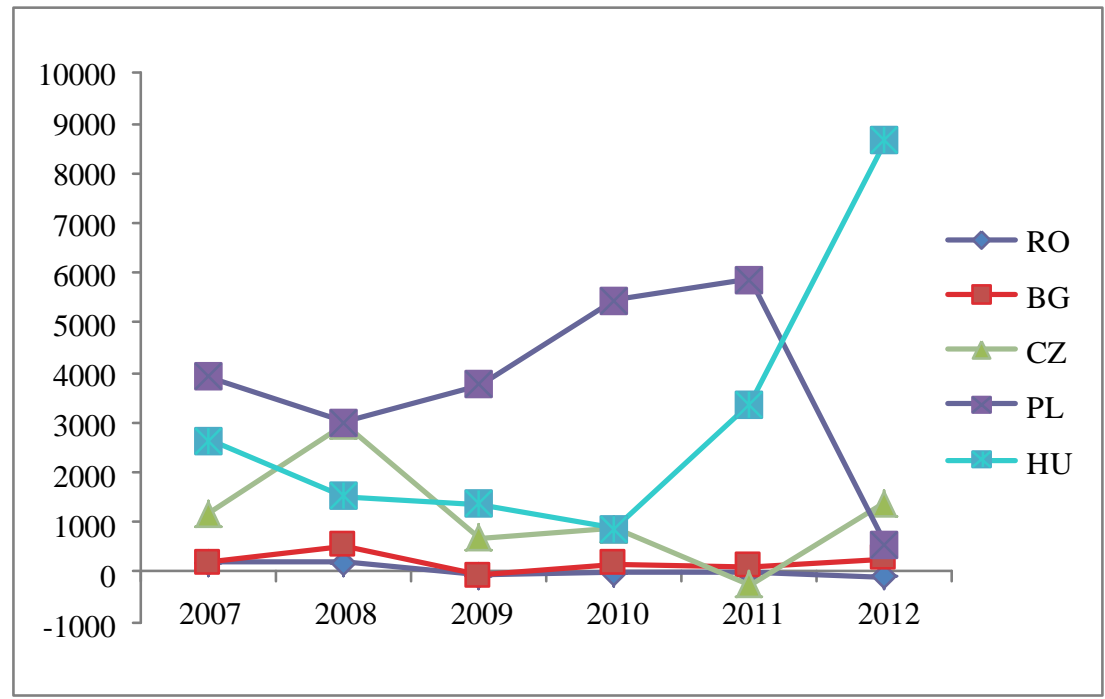

Source: Own representation, using Eurostat data

On the other side, Hungary and Poland are far away from the other three member states and even if they don't have a stable evolution, they have positive ones every year and big amounts of foreign money invested in their economies. This may be one of the reasons why these two countries recorded small budget deficits comparing with other countries during the crisis. In fact, Poland is the only country that didn't had problems with the budget deficit. They managed to keep it under control. Also, we have to mention that Poland and Bulgaria decided to deacrese social contribution rates in 2010 and this fact attracted investors to keep or even to move their businesses in these countries.

With these two comparisons we can see that fiscal changes brought in the analyzed countries influenced their strategy regarding regional development. Romania and the Czech Republic kept direct taxes unchanged or with small changes, but increased VAT and excises in order to help fiscal revenues and to reduce the budget deficit. But with this, they also recorded big losses of foreign investments, because they didn't manage to create a favorable business development environment. Bulgaria and Hungary on the other side had chosen the difficult way but with good perspectives on the long term and they decreased social contribution rates and managed to keep the lowest flat tax from the European Union in Bulgaria's case. Even if the unemployment rate for them is bigger, with a stable evolution of foreign investment in time they will fix this weak point. Poland is a 
„special case”, because authorities decided to increase VAT in 2011, but they also decreased the tax base for excises in order to encourage the international economic relations with other member states. They didn't made other changes, and this is reflected also in the stability of the unemployment rate, but also in the positive values of the foreign direct investment flows.

\section{Current approaches in Romania's fiscal system}

In order to align to other European conutries more developed and to achieve macroeconomic goals, Romania tried after the economic crisis to apply not only one measure in fiscal field. There were made changes to increase budget revenues, to decrease the budget deficit and to reach a confortable economic growth. But up to now, all these were not enough. Starting with 2016, Romania intends to implement a new Fiscal Code with a lot of changes.

We identified some of them which will meet goals of regional development policy. One of this is the extention of VAT reverse charge. If up to now only six types of business areas were eligible for a simplified tax system in terms of VAT such as supplies of grain crops (wheat, rye, barley, maize, soybean, canola, sunflower and sugar beet), delivery of waste and secondary raw materials resulted from them, the supply of wood and wooden materials, the transfer of allowances to emit greenhouse gases and the transfer of other units that may be used by operators for compliance with the same law, electricity supply by a taxable dealer and the transfer of green certificates, starting with 1st of January 2016, in the same category there will be added the supply of buildings, parts of buildings and land of any charging regime and the supply of mobile phone, integrated circuit devices, tablet PCs, laptops, game consoles, defined and delivered according to specific conditions provided by law. The VAT reverse charge brought many benefits in Romania's economy especially starting with 2011, when it became available for crops transactions. The „black economy” in the agriculture domain had been reduced a lot because all the farmers were interested in recovering VAT for other raw materials that contribute to produce the final product. In this sense, the extension of this measure to others areas of activity can contribute to the fiscal revenues and in the same time to economic growth.

Another fiscal measure which will help to implement the regional development policy is the introduction of a differentiated tax on income of $1 \%$ (instead of the $3 \%$ of revenue), which will be applied to newly established micro enterprises meeting certain conditions such as the obligation of hiring at least one employee or to ensure a continuous activity for 4 years. In this way, the state encourages new micro enterprises to be more stable and to have a favorable contribution on the labour market. 
The new fiscal code provides also tax exemption for presents given to employees which values less than about 35 euro. This will relief the employers for some expenses and in the same time it will encourage them to increase their employees number.

These are only three changes brough by the new fiscal code which will help the implementation of the regional development strategy in Romania. At the same time, as Radu C.F has highlighting in her paper „Aspects concerning tax evasion in Alba county and Brasov region", fiscal policy should bring more positive changes in favor of taxpayers because people would be interested to pay taxes because (most of them) are aware they need education, medical insurance, pensions etc. But if there is no money in the budget, they will not be able to benefit from these services. From this perspective it is more useful for people to cooperate and each to pay their tax obligations. We consider that individuals pay taxes, primarily due to real or presumed benefits that they think they can get by paying taxes. Secondly, for fear of negative consequences that may arise as a result of their nonpayment and just thirdly (and only to a small extent) due to "fiscal consciousness" and, respectively, due to a desire to help achieve "the common good" (Radu C.F, 2014).

\section{Conclusion}

The regional development policy is one of the most important and complex policies in the European Union, as its status is derived from its goal of reducing the economic and social gaps existing between different regions of Europe and it influences different domains that are important for their development, such as economic growth and small and medium enterprises (SME) sector, transports, agriculture, urban development, environmental preservation, employment and professional training, education, gender equality (Annals of the "Ovidius" University, 2011). For each period, the European Union tried to establish rules and directions for the member states in order to take a step forward to the single market. The single market can not be completly stable until all the member states will come to a similar level of economical and social development.

We saw that the strategy for 2014-2020 brought some changes, as countries are divided by their level of development established with the GDP per capita dimension. This division has the role to focus and distribute European funds in countries where the need is higher. Also the new strategy covers a very clear approach for the unemployment, because this is one of the most important indicator when we talk about labour market and fiscal revenues, for social stability which can bring also economic stability and for economic growth in general when we talk about fighting poverty.

60 DE GRUYTER OPEN
Studia Universitatis "Vasile Goldis" Arad. Economics Series Vol 26 Issue 2/2016 ISSN: 1584-2339; (online) ISSN: 2285 - 3065.

Web: publicatii.uvvg.ro/index.php/studiaeconomia.Pages $48-62$ 
In order to analyze the corelation of regional policy with fiscal policy, we exposed the fiscal changes made in the European Union's member states in 2010-2011 period and then we saw how these changes affected two significant indicators of regional development policy: unemployment rate and foreign direct investemnts.

We concluded that Romania and the Czech Republic have a quite stable evolution when we talk about unemployment rate but a worrying trend of foreign direct investment. In the crisis time, they both chose to increase indirect tax rates, but without thinking at fiscal competition and how this may affect their direct fiscal revenues.

Bulgaria chose the long term strategy and they managed to keep their flat tax very low, despite their unfavorable evolution of unemplyment rate. They were able to increase their foreign investment flows and if they keep going like this, the business environment will develop and bring growth. Hungary had chosen to decrease corporate and income tax in 2010-2011 in order to encourage employers and the business environment in general to invest in their country and to keep their anctiviy in Hungary. They succeede if we notice the stability of unemployment rate after 2010 and the favorable level of foreign investemnts attracted.

The last country analyzed was Poland, which managed to keep their direct taxes unchanged, to increase VAT rate but at the same time to decrease the tax base for excises in order to encourage the transactions between them and other member states. Poland had a stable evolution for unemployment and the biggest flows of foreign direct investments excepting 2012. But it is worth to mention that is the only country form the five analyzed that had positive values every year.

In the last part of the paper we mentioned the new fiscal code which will be implemented in Romania starting with 1st of January 2016, that will bring some changes in line with regional development policy's requirements. Extending VAT reverse charge, decreasing corporate tax for new micro-enterprises or providing some tax exemptions for employers are some measures taken in order to encourage the business enviornment, to reduce the unemployment rate and to bring economic growth.

There is no doubt that fiscal policies chosen to be applied influence in a direct way how member states manage to develop the European Union's regional policy. After they faced an economic crisis with devastating effects, authorities seem to understand now that the fiscal measures don't have to bring only increased fiscal revenues in a short term. They must ensure a stable economic environment and encourage a constant development for domains that can build a single market at the European Union's level. In this way, in crisis times, the effects will be less harmfull and the recovery faster. 
Vlad C., Brezeanu P. (2016)

Fiscality - a relevant factor influencing regional development in Romania and the European Union

\section{References}

1. Andrei T., Stancu S., (2008), Econometric methods used to study the informal economy and regional development, Informatica Economica Bulletin no. 3, pg. 120-128

2. Cziraki D., Regional development in Croatia

3. Dascalu I., Cojocaru A. (2011), Perspective comparate privind taxarea, nivelul castigului si sustenabilitatea in Uniunea Europeana

4. Dornean A. (2015), Financing regional development through european funds. A review of the effects in Romania (2007-2013), Eurint Proceedings ISSN 2393-2384

5. European Comission Report (2012), Tax reforms in EU member states

6. European Comission Report (2015), Study on the effects and incidence of labour market

7. Gale G. W., Krupkin A., Rueben K., (2015), The relationship between taxes and growth at the state level: new evidence

8. Kuznets, S. (1966), Modern Economic Growth. New Haven: Yale University Press

9. Mackay R.R. (2003), Twenty five years of regional development, Regional Studies, Volume 37, Issue 3

10. Nedelea, A1., 2005, Regionalization, Regional Development and Cooperation in Eastern Europe, Economy and Transition, Albanian Center of Economic Research, no. 3, Tirana

11. Popescu M., Nastase C., Scutariu L., (2009), Regional Development in the context of the European Union Integration the Annals of The "Stefan cel Mare" University Suceava. Fascicle of The Faculty of Economics and Public Administration, Vol. 9, pg 51-56

12. Prammer D. (2011), Quality of taxation and the crisis: tax shifts from a growth perspective, European Comission, Taxation paper no. 29

13. Radu C. F., (2014), Aspects concerning tax evasion in Alba county and Brasov region, Economics Series Vol 24 Issue 1/2014

14. Radu C.F., Dumiter F., Opret A.L. (2015), Labour taxation - a comparative study, Economics Series 2015

15. Sabau M. et al, Regional Development in Romania

16. Salvador B. et al (2014), Effective corporate taxation, tax incidence and tax reforms: evidence from OECD countries, European Comission, Taxation paper no. 45

17. Sandmo, A. (1981), Income Tax Evasion, Labour Supply,and the Equity-Efficiency Tradeoff, Journal of Public Economics, 16(3)

18. Smith, S. (1986): Britain's Shadow Economy, Clarendon Press, Oxford

Tsuru, K. (2000), Finance and growth, OECD Economics Department Working Paper 228

19. Werner D. (2014), New insights into the development of regional unemployment disparities, Institute for Employment Research (IAB), Germany

20. Wisnewiski A. (2005), The impact of foreign direct investment on regional development in Poland, Institute for world economics Hungarian Academy of Science Working Papers, No. 162

21. www.eurostat.ro

22. www. europa.eu

62 DE GRUYTER OPEN
Studia Universitatis "Vasile Goldis" Arad. Economics Series Vol 26 Issue 2/2016 ISSN: 1584-2339; (online) ISSN: 2285 - 3065.

Web: publicatii.uvvg.ro/index.php/studiaeconomia.Pages $48-62$ 